\title{
Familial Cancer of the Colon and Rectum
}

\author{
G. H. DUNSTONE* and T. W. L. KNAGGS $\dagger$
}

A familial relationship between intestinal polyposis and the predisposition of polyposis to colonic cancer has been accepted since the publication in 1952/1953 of Dukes's paper. He collected information on every patient presenting at St Mark's Hospital with polyposis coli and investigated the family background in each case. He was able to study 41 families, trace 156 cases of polyposis, and 114 cases of cancer of colon and rectum in this group of families. Other diseases are known to predispose to the development of colonic and rectal cancer. The most clearly documented of these is ulcerative colitis in which a polygenic aetiology has been suggested (McConnell, 1966). Solitary colonic polyps have been considered by some recent authors (Woolf, Richards, and Gardner, 1955; Morson and Bussey, 1970) to have a familial relationship, and some of these polyps are regarded as precancerous.

By contrast, the presence of a familial tendency to cancer of the colon has only rarely been reported (Kluge, 1964; Fielding, 1969). In postulating a familial predisposition to cancer of the colon, one must take into account that this is a common disease in the western world (accounting for $2.6 \%$ of all deaths in England and Wales in 1969 and $13.9 \%$ of all cancer deaths) and consequently the fact that several members of a family die of this disease may be purely coincidental. The present report concerns a large family in which the incidence of colonic cancer appears too great to be attributed to chance.

\section{Materials and Methods}

Our interest in this family (see pedigree in Fig. 1) was first aroused when one of its members (IV.13) presented with a vesicocolic fistula due to cancer of the pelvic colon. He remarked that all the members of his family died of cancer of the bowel. Our offer to review the surviving members was not accepted at that stage (1967).

In the following year one of the sisters of this patient was diagnosed at another hospital as having a cancer of the splenic flexure (IV.14) and although she had an apparently successful resection in the absence of obvious

Received 17 May 1972.

* Consultant Surgeon, Durham Hospital Group.

+ General Practitioner, Coxhoe, County Durham. secondary deposits, she died in 1969 with generalized carcinomatosis. The remainder of this sibship of the family then presented for examination and within a short time one of them (IV.15) was found to have a small rectal cancer with a large tumour in the transverse colon. She was treated by a total colectomy and it was in this specimen that the only benign polyp recorded in the whole group was found.

It was decided at this stage to try to trace the remaining members of the family and to look into the cause of death of such members as we were able to trace. The family proved a large one and the task was therefore quite formidable, but it was helped in part by the fact that most members had lived and died in a fairly circumscribed area. The total number of members of this family we have been able to trace is 104 in 4 generations. Another generation exists but is as yet too young to be affected, although one of our aims is to attempt to identify the members of this generation who are at risk so that we can if possible prevent the disease taking as heavy a toll in the future as it has done in the past.

Causes of death have been obtained from death certificates, general practitioners, and where possible from hospital records, but even where the latter have been available it has not always proved possible to be precise with regard to the part of the colon involved.

In many of the earlier cases, we have had to rely on the information on death certificates which have not been substantiated by necropsies, but in the majority (18 out of 24) of the more recent cases (in generations III and IV), hospital records with details of operative findings have been made available to us, and in most of these (14) there has been histological confirmation of the diagnosis.

\section{Results}

The details of findings are summarized in the Appendix (pp. 455-456) and in Fig. 1. Each member of the family can be assigned to one of 4 groups which have been indicated both in the Appendix and in the family tree.

Group a Those individuals, both alive and dead, in whom the diagnosis of colonic cancer seems definite. These number 25 .

Group b A few cases in which there seems to be some doubt as to whether there was a cancer of the colon or not. These number 5 . 


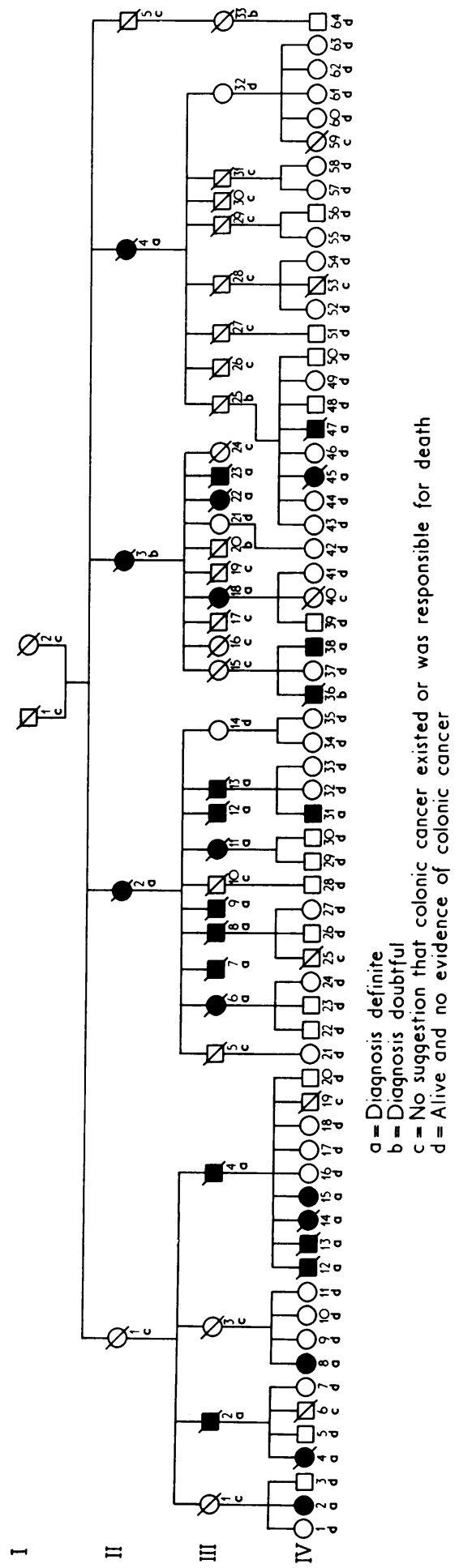

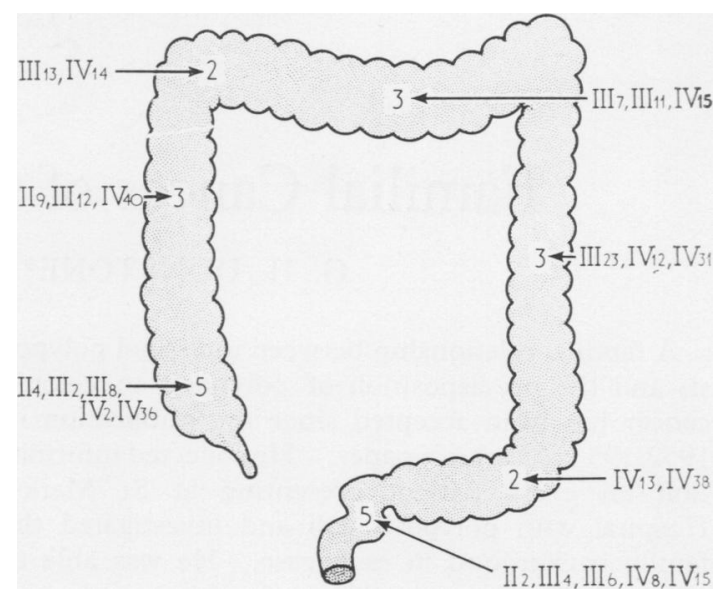

Fig. 2

Group c Those who have died without any suggestion that colonic cancer was responsible. These number 25 .

Group d Those remaining alive who as yet show no evidence of colonic cancer. These number 49.

Groups a, c, and d need no special explanation but group $b$ contains 5 individuals in whom we feelo there may be some doubt as to whether cancer of the colon was responsible for their death. The details of their clinical histories are as follows:

II.3. This woman born in 1861 and dying in 1917 at the age of 56 was not in hospital, was never operated on, but her death certificate records that she died of carcinoma of the liver of 9 months' duration. It seems highly likely that the liver tumour was secondary to some primary neoplasm, and the survival for 9 months after diagnosis is probably as much in keeping with a colonic primary as anywhere else in the gastrointestinal tract. We have therefore included this patient as an affected member in the family.

III.20. This man born in 1891 and dying in 1920 at the age of 28 suffered from a combination of haemorrhage from the bowel and peritonitis due, according to his death certificate, to ulceration of the colon. From the information available, ulcerative colitis seems the likely diagnosis. We have not considered him as a case of colonic cancer.

III.25. This man born in 1888 and dying in 1951 at the age of 63 was operated on in hospital but unfortunately the records have been destroyed. His death certificate gives the cause of death as tuberculosis of the caecum which was commonly confused with Crohn's disease, rather than cancer. We have not included this man as a case of colonic cancer. 
III.33. This woman born in 1908 and dying in 1931 at the age of 23 years, died during induction of anaesthesia for what the death certificate records as malignant disease of the pelvis. No necropsy was performed, and there is no indication as to whether this was a tumour of the bowel or the reproductive organs. We have not included this as a case of colonic cancer.

IV.36. This man born in 1907 and dying in 1945 at the age of 38, was operated on in hospital, and although his death certificate records death due to carcinoma of the ileum, the operation records describe a tumour involving caecum and terminal ileum from which no tissue was taken for histology. It seems quite likely that the caecum was the site of his primary tumour. We have therefore included this patient as an affected member in the family.

Age at Death. The age of onset of the disease proved impossible to ascertain from the information available to us, and we therefore limited our observations to the age at death.

In most of the cases, surgical treatment seems to have had little effect on survival as diagnosis has tended to be late, and life thereafter short. There are, of course, a few exceptions to this statement. The average age at death of affected members in the last 3 generations has been as follows. In generation II there were 3 affected members; average age at death $61 \cdot 7$ years. In generation III there were 12 affected members; average age at death 50 years. In generation IV there were 7 affected members; average age at death $42 \cdot 6$ years.

Sex Incidence. Of the total deaths to date in this family 50 have been traced, of which 30 have been male and 20 female. Of these, 22 were affected by colonic cancer, 12 males and 10 females. There is no significant difference in sex incidence.

Inheritance. The findings suggest that cancer of the colon and rectum is an inherited disease in this family, due to a single gene behaving as a dominant. There are a few exceptions to regular transmission indicating slightly reduced penetrance, but there are 15 affected out of the 29 members of affected sibships in generations II and III, and 27 affected out of the 63 members of all affected sibships, including generation IV where some may not yet have attained the age of onset. These figures are very close to those for a single gene dominant character.

Penetrance is however high. Of a total of 33 members who must carry the affected gene if this disorder is behaving in a dominant fashion, 27 suffered from the disease, a penetrance of $82 \%$, and if 2 possible carriers (I.1 and II.1) are regarded as positives the figure rises to $88 \%$.

The 6 non-affected carriers are as follows.
I.1 or I.2. The only evidence as to the cause of death in these 2 individuals comes from death certificates. There is a possibility that cirrhosis given as the cause of death in I.1 may have been a mistaken diagnosis for carcinomatosis with secondary deposits in the liver. In the case of $I .2$ senility at the age of 78 gives no suggestion of any possible colonic lesion.

II.1. This woman died at the age of 36 years from tuberculous peritonitis in pregnancy. She may well have carried the affected gene which had not manifested itself before her death.

III.1. This woman died at the age of 83 years. The death certificate gave the cause as cerebral thrombosis. It is clear that carcinoma of the colon cannot be implicated in this case.

III.3. This woman died at the age of 77 years from cardiac failure, and there is no suggestion that she may have had colonic cancer.

III.15. This woman died at the age of 83 years from cerebral thrombosis without evidence of cancer.

III.25. This man was discussed under the doubtful cases, and the conclusion reached that he suffered from either a tuberculous caecum or Crohn's disease. He died at the age of 63 , so that it is likely he would have manifested colonic cancer before this age although a few cases presenting at later ages exist in the family.

\section{Discussion}

There is strong evidence for supposing that cancer of the colon and rectum is inherited as a dominant characteristic in this family. Twentyseven cases have already manifested themselves whilst many members of the family are still in the age groups who could yet develop the disease. Of the total deaths traced in the whole family, which number 50, no fewer than 22 have been due to cancer of the colon or rectum, 5 affected members still survive. The total deaths include several individuals dying from accident or natural causes at ages lower than those at which cancer has usually developed.

There is no reason to suppose that this family carries the gene of multiple polyposis, since polyps have not been a feature demonstrated by sigmoidoscopic or radiological investigation, nor have they been present in the pathological material studied, with the exception of the solitary benign polyp in case IV.15. In addition, the age of onset of symptoms in this family has been consistently higher than the average age of onset of symptoms in series of cases of multiple polyposis. In the 1952/1953 series of Dukes, for example, the average age of onset of symptoms was $21 \cdot 1$ years. Finally, the cases in this series have not given a long history of rectal 
bleeding before the development of carcinoma as is common in cases of polyposis.

The possibility exists that any common disease will occur by chance in several members of a family. But the very high incidence in this family and the relatively large numbers of individuals involved, make this a very unlikely explanation, in our opinion.

Environmental factors are known to play a part in the aetiology of colonic neoplasms (Burkitt, 1969) and primitive African societies have a low incidence of the disease, while Africans exposed to a western type society have an incidence which is climbing rapidly to that of the European members of the society. Burkitt suggests that the dietary factors, particularly the low roughage diet of western society, are primarily involved. It is difficult to postulate any environmental basis in the family we are reporting, in that although they have tended to live their lives in a fairly circumscribed area, they do not seem to have any special family quirks with regard to their dietary habits. In addition, a great many other people live in the same area, and do not show the massive incidence of colonic and rectal neoplasm.

As a genetic phenomenon we find this an interesting family, but our aim is more than passive observation. In the interests of the surviving members of this family and their descendants it is of vital importance that they should be kept under continuing surveillance, so that new cases or cancer can be detected early and so that potentially successful treatment can be instituted. Even more desirable would be the detection of those individuals at risk before the disease develops. This would allow a $\underset{\mathbb{D}}{\mathscr{T}}$ concentration of diagnostic effort in follow up, and if found to be reliable, might justify prophylactic colectomy.

Our grateful thanks to those surgeons and family doctors who made their records freely available to us, to the members of the family for their cooperation in preparing the family tree and in their willingness to undergo $\mathrm{c}$ examination and repeated investigations, and to Professor E. J. Field and Professor Sir David Smithers for the tests they have performed in an effort to identify the individuals at risk. Our special thanks to Dr D. F. Roberts of the Department of Human Genetics, Newcastle University, for his enthusiastic encouragement and a great deal of practical help in the preparation of this paper. Finally, our thanks to our wives for many i lost evenings, suffered without complaint, and a great deal of secretarial assistance.

\section{REFERENCES}

Burkitt, D. F. (1969). Related disease-related cause? Lancet, 2 1229-1231.

Dukes, C. E. (1952/1953). Familial intestinal polyposis. Annals of Eugenics, 17, 1-29.

Fielding, J. F. (1969). Familial non-polypotic carcinoma of colon. British Medical fournal, 1, 512-513.

Kluge, T. (1964). Familial cancer of the colon. Acta Chirurgica Scandinavica, 127, 392-398.

McConnell, R. B. (1966). The genetics of gastro-intestinal disê orders, pp. 135-136. Oxford University Press, London.

Morson, B. C. and Bussey, H. J. R. (1970). Predisposing causes of intestinal cancer. Current Problems in Surgery, February. Yex? Book Medical Publishers, Chicago.

Woolf, C. M., Richards, R. C., and Gardner, E. J. (1955). Occasional discrete polyps of the colon and rectum showing an inherited tendency in a kindred. Cancer, 8, 403-408. 


\section{Appendix}

\begin{tabular}{|c|c|c|c|c|c|c|}
\hline Case & Year of Birth & Age* & Sex & Remarks & Sourcet & Group $\ddagger$ \\
\hline I.1 & $\begin{array}{l}1825 \\
1823\end{array}$ & $\begin{array}{l}(60) \\
(78)\end{array}$ & $\begin{array}{l}\mathbf{M} \\
\mathbf{F}\end{array}$ & $\begin{array}{l}\text { Cirrhosis of liver } \\
\text { Senility }\end{array}$ & $\begin{array}{l}\text { DC } \\
\text { DC }\end{array}$ & $\begin{array}{l}\text { c } \\
\text { c }\end{array}$ \\
\hline $\begin{array}{l}\text { III.1 } \\
\text { II. } \\
\text { II. } \\
\text { II. } \\
\text { II. } \\
\end{array}$ & $\begin{array}{l}1857 \\
1859 \\
1861 \\
1863 \\
1868\end{array}$ & $\begin{array}{l}(36) \\
(65) \\
(56) \\
(55) \\
(43)\end{array}$ & $\begin{array}{l}\mathrm{F} \\
\mathrm{F} \\
\mathrm{F} \\
\mathrm{M}\end{array}$ & $\begin{array}{l}\text { TB; peritonitis; pregnancy } \\
\text { Carcinoma of the rectum } \\
\text { Carcinoma of the liver; no operation or necropsy } \\
\text { Carcinoma of the caecum } \\
\text { TB; peritonitis }\end{array}$ & $\begin{array}{l}\mathrm{DC} \\
\mathrm{DC} \\
\mathrm{DC} \\
\mathrm{DC} \\
\mathrm{DC}\end{array}$ & $\begin{array}{l}\text { c } \\
\mathbf{a} \\
\mathbf{b} \\
\mathbf{a} \\
\mathbf{c}\end{array}$ \\
\hline $\begin{array}{l}\text { III.1 } \\
\text { III.2 } \\
\text { III. } 3 \\
\text { III.4 } \\
\text { III.5 }\end{array}$ & $\begin{array}{l}1877 \\
1884 \\
1886 \\
1892 \\
1879\end{array}$ & $\begin{array}{l}(83) \\
(47) \\
(77) \\
(46) \\
(33)\end{array}$ & $\begin{array}{l}\mathrm{F} \\
\mathrm{M} \\
\mathrm{F} \\
\mathrm{M}\end{array}$ & $\begin{array}{l}\text { Cerebral thrombosis } \\
\text { Carcinoma of the caecum; operation } \\
\text { Acute cardiac failure } \\
\text { Carcinoma of the rectum } \\
\text { Mining accident }\end{array}$ & $\begin{array}{l}\text { DC } \\
\text { HR } \\
\text { DC } \\
\text { DC } \\
\text { R }\end{array}$ & $\begin{array}{l}\text { c } \\
\text { a } \\
\text { c } \\
\text { a } \\
\text { c }\end{array}$ \\
\hline $\begin{array}{l}\text { III.6 } \\
\text { III.7 } \\
\text { III.8 } \\
\text { III.9 } \\
\text { III. } 10\end{array}$ & $\begin{array}{l}1882 \\
1884 \\
1888 \\
1890 \\
1892\end{array}$ & $\begin{array}{l}(28) \\
(51) \\
(50) \\
(39) \\
(42)\end{array}$ & $\begin{array}{l}\mathbf{F} \\
\mathbf{M} \\
\mathbf{M} \\
\mathbf{M}\end{array}$ & $\begin{array}{l}\text { Carcinoma of the rectum } \\
\text { Carcinoma of transverse colon; necropsy } \\
\text { Carcinoma of the caecum; operation } \\
\text { Carcinoma of ascending colon; operation } \\
\text { Pulmonary TB; laparotomy performed }\end{array}$ & $\begin{array}{l}\text { DC } \\
\text { HR } \\
\text { HR } \\
\text { HR } \\
\text { DC and R }\end{array}$ & $\begin{array}{l}\mathbf{a} \\
\mathbf{a} \\
\mathbf{a} \\
\mathbf{a} \\
\mathbf{c}\end{array}$ \\
\hline $\begin{array}{l}\text { III.11 } \\
\text { III.12 } \\
\text { III.13 }\end{array}$ & $\begin{array}{l}1893 \\
1897 \\
1900\end{array}$ & $\begin{array}{l}(69) \\
(47) \\
(56)\end{array}$ & $\begin{array}{l}\mathbf{F} \\
\mathbf{M}\end{array}$ & $\begin{array}{l}\text { Carcinoma of transverse colon; operation } \\
\text { Carcinoma of ascending colon; operation } \\
\text { Carcinoma of hepatic flexure of colon with involvement of } \\
\text { duodenum }\end{array}$ & $\begin{array}{l}\text { HR } \\
\text { HR } \\
\text { HR }\end{array}$ & $\begin{array}{l}\mathbf{a} \\
\mathbf{a} \\
\mathbf{a}\end{array}$ \\
\hline $\begin{array}{l}\text { III.14 } \\
\text { III.15 }\end{array}$ & $\begin{array}{l}1902 \\
1881\end{array}$ & $\begin{array}{l}69 \\
(84)\end{array}$ & $\begin{array}{l}\mathbf{F} \\
\mathbf{F}\end{array}$ & $\begin{array}{l}\text { Alive and well } \\
\text { Cerebral thrombosis }\end{array}$ & DC & $\begin{array}{l}\text { d } \\
\mathbf{c}\end{array}$ \\
\hline $\begin{array}{l}\text { III.16 } \\
\text { III.17 } \\
\text { III.18 } \\
\text { III.19 } \\
\text { III. } 20\end{array}$ & $\begin{array}{l}1884 \\
1886 \\
1888 \\
1891 \\
1891\end{array}$ & $\begin{array}{l}(48) \\
(65) \\
(58) \\
(23) \\
(28)\end{array}$ & $\begin{array}{l}\mathbf{F} \\
\mathbf{M} \\
\mathbf{M} \\
\mathbf{M}\end{array}$ & $\begin{array}{l}\text { Carcinoma of stomach } \\
\text { Pulmonary embolus; deep vein thrombosis } \\
\text { Carcinoma of colon } \\
\text { Killed in action } \\
\text { Ulceration of colon; peritonitis }\end{array}$ & $\begin{array}{l}\text { DC } \\
\text { DC } \\
\text { DC } \\
\text { R } \\
\text { DC }\end{array}$ & $\begin{array}{l}\text { c } \\
\text { c } \\
\text { a } \\
\text { c } \\
\text { b }\end{array}$ \\
\hline $\begin{array}{l}\text { III. } 21 \\
\text { III. } 22 \\
\text { III. } 23 \\
\text { III. } 24 \\
\text { III. } 25\end{array}$ & $\begin{array}{l}1894 \\
1896 \\
1899 \\
1902 \\
1888\end{array}$ & $\begin{array}{l}77 \\
(47) \\
(64) \\
(45) \\
(63)\end{array}$ & $\begin{array}{l}\mathbf{F} \\
\mathbf{F} \\
\mathbf{M} \\
\mathbf{F}\end{array}$ & $\begin{array}{l}\text { Alive and well } \\
\text { Carcinoma of colon } \\
\text { Carcinoma of descending colon; inoperable at operation } \\
\text { Carcinoma of uterus } \\
\text { TB caecum; operation, but records no longer available }\end{array}$ & $\begin{array}{l}\text { DC } \\
\text { HR } \\
\text { DC } \\
\text { DC }\end{array}$ & $\begin{array}{l}\mathbf{a} \\
\mathbf{a} \\
\mathbf{c} \\
\mathbf{b}\end{array}$ \\
\hline $\begin{array}{l}\text { III. } 26 \\
\text { III. } 27 \\
\text { III. } 28 \\
\text { III. } 29 \\
\text { III. } 30\end{array}$ & $\begin{array}{l}1889 \\
1891 \\
1893 \\
1898 \\
1900\end{array}$ & $\begin{array}{l}(71) \\
(49) \\
(77) \\
(65) \\
(69)\end{array}$ & $\begin{array}{l}M \\
M \\
M \\
M \\
M\end{array}$ & $\begin{array}{l}\text { Congestive heart failure } \\
\text { Road accident } \\
\text { Senility } \\
\text { Carcinoma of kidney } \\
\text { Carcinoma of lung }\end{array}$ & $\begin{array}{l}\text { GP } \\
\mathbf{R} \\
\text { GP } \\
\text { HR } \\
\text { GP }\end{array}$ & $\begin{array}{l}\text { c } \\
\text { c } \\
\text { c } \\
\text { c } \\
\text { c }\end{array}$ \\
\hline $\begin{array}{l}\text { III. } 31 \\
\text { III. } 32 \\
\text { III. } 33\end{array}$ & $\begin{array}{l}1904 \\
1906 \\
1908\end{array}$ & $\begin{array}{l}(67) \\
65 \\
(24)\end{array}$ & $\begin{array}{l}\mathbf{M} \\
\mathbf{F} \\
\end{array}$ & $\begin{array}{l}\text { Carcinoma of lung } \\
\text { Alive and well } \\
\text { Malgnant disease of pelvis; no operation; no necropsy }\end{array}$ & $\begin{array}{l}\text { HR } \\
\text { DC }\end{array}$ & $\begin{array}{l}\mathbf{c} \\
\mathbf{d} \\
\mathbf{b}\end{array}$ \\
\hline $\begin{array}{l}\text { IV.1 } \\
\text { IV.2 } \\
\text { IV.3 } \\
\text { IV.4 } \\
\text { IV.5 }\end{array}$ & $\begin{array}{l}1902 \\
1904 \\
1907 \\
1916 \\
1919\end{array}$ & $\begin{array}{c}69 \\
67 \\
64 \\
(45) \\
42\end{array}$ & $\begin{array}{l}\mathbf{F} \\
\mathbf{F} \\
\mathbf{M} \\
\mathbf{M}\end{array}$ & $\begin{array}{l}\text { Alive and well } \\
\text { Resection carcinoma of caecum at age } 65 \text {; remains alive and well } \\
\text { Alive and well } \\
\text { Carcinima of colon } \\
\text { Alive and well }\end{array}$ & HR & $\begin{array}{l}\text { d } \\
\text { a } \\
\text { d } \\
\text { a } \\
\text { d }\end{array}$ \\
\hline $\begin{array}{l}\text { IV.6 } \\
\text { IV.7 } \\
\text { IV.8 }\end{array}$ & $\begin{array}{l}1921 \\
1925 \\
1909\end{array}$ & $\begin{array}{l}(23) \\
46 \\
62\end{array}$ & $\begin{array}{l}\mathbf{M} \\
\mathbf{F}\end{array}$ & $\begin{array}{l}\text { Cerebral tumour; operation; no records } \\
\text { Alive and well } \\
\text { Resection of papillary carcinoma of rectum at age } 50 \text {; alive and } \\
\text { well }\end{array}$ & $\begin{array}{l}\text { DC } \\
\text { HR }\end{array}$ & $\begin{array}{l}\mathbf{c} \\
\mathbf{d} \\
\mathbf{a}\end{array}$ \\
\hline $\begin{array}{l}\text { IV.9 } \\
\text { IV. } 10\end{array}$ & $\begin{array}{c}1915 \\
?\end{array}$ & 66 & $\mathbf{F}$ & $\begin{array}{l}\text { Alive and well } \\
\text { Alive and well }\end{array}$ & & $\begin{array}{l}\mathbf{d} \\
\mathbf{d}\end{array}$ \\
\hline $\begin{array}{l}\text { IV.11 } \\
\text { IV.12 } \\
\text { IV.13 } \\
\text { IV.14 } \\
\text { IV.15 }\end{array}$ & $\begin{array}{c}? \\
1920 \\
1924 \\
1926 \\
1928\end{array}$ & $\begin{array}{c}(44) \\
(43) \\
(43) \\
43\end{array}$ & $\begin{array}{l}\mathbf{F} \\
\mathbf{M} \\
\mathbf{M} \\
\mathbf{F} \\
\mathbf{F}\end{array}$ & $\begin{array}{l}\text { Alive and well } \\
\text { Carcinoma of descending colon } \\
\text { Carcinoma of pelvic colon } \\
\text { Carcinoma of hepatic flexure of colon } \\
\text { Resection carcinoma of transverse colon and carcinoma of } \\
\text { rectum at age } 42 \\
\text { Single benign polyp found in the specimen of the colon; alive } \\
\text { and well }\end{array}$ & $\begin{array}{l}\text { HR } \\
\text { HR } \\
\text { HR } \\
\text { HR }\end{array}$ & $\begin{array}{l}\text { d } \\
\mathbf{a} \\
\mathbf{a} \\
\mathbf{a} \\
\mathbf{a}\end{array}$ \\
\hline $\begin{array}{l}\text { IV.16 } \\
\text { IV.17 } \\
\text { IV.18 } \\
\text { IV.19 } \\
\text { IV.20 }\end{array}$ & $\begin{array}{l}1930 \\
1932 \\
1934 \\
1936 \\
1938\end{array}$ & $\begin{array}{c}41 \\
39 \\
37 \\
(25) \\
33\end{array}$ & $\begin{array}{l}F \\
F \\
F \\
M \\
M\end{array}$ & $\begin{array}{l}\text { Alive and well } \\
\text { Alive and well } \\
\text { Alive and well } \\
\text { Asthma } \\
\text { Alive and well }\end{array}$ & DC & $\begin{array}{l}\mathbf{d} \\
\mathbf{d} \\
\mathbf{d} \\
\mathbf{c} \\
\mathrm{d}\end{array}$ \\
\hline $\begin{array}{l}\text { IV.21 } \\
\text { IV.22 } \\
\text { IV.23 } \\
\text { IV.24 } \\
\text { IV.25 }\end{array}$ & $\begin{array}{l}1905 \\
1903 \\
1905 \\
1908 \\
1915\end{array}$ & $\begin{array}{l}66 \\
68 \\
66 \\
63 \\
(38)\end{array}$ & $\begin{array}{l}\mathbf{F} \\
\mathbf{M} \\
\mathbf{F} \\
\mathbf{M}\end{array}$ & $\begin{array}{l}\text { Alive and well } \\
\text { Alive and well } \\
\text { Alive and well } \\
\text { Alive and well } \\
\text { Perforated duodenal ulcer }\end{array}$ & DC & $\begin{array}{l}\mathbf{d} \\
\mathbf{d} \\
\mathbf{d} \\
\mathbf{d} \\
\mathbf{c}\end{array}$ \\
\hline
\end{tabular}

* Age at death is given in parentheses.

$+\mathrm{DC}=$ death certificate; $\mathrm{HR}=$ hospital records; $\mathbf{R}=$ other records; $\mathrm{GP}=$ family doctor.

¥ For code a, b, c, d, see Fig. 1 . 
Appendix-continued

\begin{tabular}{|c|c|c|c|c|c|c|}
\hline Case & Year of Birth & Age* & Sex & Remarks & Sourcet & Group $\ddagger$ \\
\hline $\begin{array}{l}\text { IV.26 } \\
\text { IV.27 } \\
\text { IV.28 } \\
\text { IV.29 } \\
\text { IV.30 }\end{array}$ & $\begin{array}{c}1918 \\
1920 \\
? \\
1916 \\
1919\end{array}$ & $\begin{array}{l}53 \\
51 \\
55 \\
52\end{array}$ & $\begin{array}{l}M \\
\mathbf{F} \\
M \\
M \\
M\end{array}$ & $\begin{array}{l}\text { Alive and well } \\
\text { Alive and well } \\
\text { Alive and well } \\
\text { Alive and well } \\
\text { Alive and well }\end{array}$ & & $\begin{array}{l}\text { d } \\
\text { d } \\
\text { d } \\
d \\
d\end{array}$ \\
\hline IV.31 & 1926 & 46 & $\mathbf{M}$ & $\begin{array}{l}\text { Resection carcinoma descending colon in } 1970 \text {; alive but with } \\
\text { recurrence } 1971\end{array}$ & HR & a \\
\hline $\begin{array}{l}\text { IV.32 } \\
\text { IV.33 } \\
\text { IV.34 } \\
\text { IV.35 }\end{array}$ & $\begin{array}{c}1929 \\
1939 \\
? \\
?\end{array}$ & $\begin{array}{l}42 \\
32\end{array}$ & $\begin{array}{l}\mathbf{F} \\
\mathbf{F} \\
\mathbf{F}\end{array}$ & 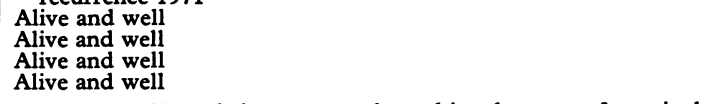 & & $\begin{array}{l}\mathbf{d} \\
\mathbf{d} \\
\mathbf{d} \\
\mathbf{d}\end{array}$ \\
\hline IV.36 & 1907 & (38) & $\mathbf{M}$ & $\begin{array}{l}\text { Carcinoma of bowel; laparotomy showed involvement of terminal } \\
\text { ileum and caecum but pathological confirmation of primary } \\
\text { site was not obtained }\end{array}$ & HR & $\mathbf{b}$ \\
\hline $\begin{array}{l}\text { IV.37 } \\
\text { IV.38 }\end{array}$ & $\begin{array}{l}1916 \\
1920\end{array}$ & $\begin{array}{l}55 \\
51\end{array}$ & $\begin{array}{l}\mathrm{F} \\
\mathbf{M}\end{array}$ & $\begin{array}{l}\text { Carcinoma of cervix } 1971 \text {; alive } \\
\text { Inoperable carcinoma of pelvic colon diagnosed at laparotomy } \\
1971 \text {; alive }\end{array}$ & $\begin{array}{l}\text { HR } \\
\text { HR }\end{array}$ & d \\
\hline $\begin{array}{l}\text { IV.39 } \\
\text { IV.40 }\end{array}$ & $\begin{array}{c}1915 \\
?\end{array}$ & $\begin{array}{l}56 \\
(?)\end{array}$ & $\begin{array}{l}\mathbf{M} \\
\mathbf{F}\end{array}$ & $\begin{array}{l}\text { Alive and well } \\
\text { Died childbirth } 1948\end{array}$ & $\mathbf{R}$ & $\begin{array}{l}\text { d } \\
\mathbf{c}\end{array}$ \\
\hline $\begin{array}{l}\text { IV.41 } \\
\text { IV.42 } \\
\text { IV.43 } \\
\text { IV.44 } \\
\text { IV.45 }\end{array}$ & $\begin{array}{l}1920 \\
1923 \\
1918 \\
1923 \\
1925\end{array}$ & $\begin{array}{c}51 \\
48 \\
53 \\
48 \\
(45)\end{array}$ & $\begin{array}{l}F \\
F \\
F \\
F \\
F\end{array}$ & $\begin{array}{l}\text { Alive and well } \\
\text { Alive and well } \\
\text { Alive and well } \\
\text { Alive and well } \\
\text { Carcinoma of the colon }\end{array}$ & HR & $\begin{array}{l}\mathbf{d} \\
\mathbf{d} \\
\mathbf{d} \\
\mathbf{d} \\
\mathbf{a}\end{array}$ \\
\hline $\begin{array}{l}\text { IV.46 } \\
\text { IV.47 } \\
\text { IV.48 } \\
\text { IV.49 } \\
\text { IV.50 }\end{array}$ & $\begin{array}{l}1927 \\
1930 \\
1932 \\
1932 \\
1936\end{array}$ & $\begin{array}{l}44 \\
(40) \\
39 \\
39 \\
35\end{array}$ & $\begin{array}{l}\mathbf{F} \\
M \\
M \\
F \\
M\end{array}$ & $\begin{array}{l}\text { Alive and well } \\
\text { Carcinoma of ascending colon; operation } 1966 \\
\text { Alive and well } \\
\text { Alive and well } \\
\text { Alive and well }\end{array}$ & HR & $\begin{array}{l}\mathbf{d} \\
\mathbf{a} \\
\mathbf{d} \\
\mathbf{d} \\
\mathbf{d}\end{array}$ \\
\hline $\begin{array}{l}\text { IV.51 } \\
\text { IV.52 } \\
\text { IV.53 } \\
\text { IV.54 } \\
\text { IV.55 }\end{array}$ & $\begin{array}{l}1935 \\
1917 \\
1919 \\
1924 \\
1920\end{array}$ & $\begin{array}{c}36 \\
54 \\
(50) \\
47 \\
51\end{array}$ & $\begin{array}{l}\mathbf{M} \\
\mathbf{M} \\
\mathrm{F} \\
\mathbf{F}\end{array}$ & $\begin{array}{l}\text { Alive and well } \\
\text { Alive and well } \\
\text { Carcinoma of lung } \\
\text { Alive and well } \\
\text { Alive and well }\end{array}$ & HR & $\begin{array}{l}\text { d } \\
\mathbf{d} \\
\mathbf{c} \\
\mathbf{d} \\
\mathbf{d}\end{array}$ \\
\hline $\begin{array}{l}\text { IV.56 } \\
\text { IV.57 } \\
\text { IV.58 } \\
\text { IV.59 } \\
\text { IV.60 }\end{array}$ & $\begin{array}{l}1930 \\
1934 \\
1936 \\
1932 \\
1934\end{array}$ & $\begin{array}{c}41 \\
37 \\
35 \\
(34) \\
37\end{array}$ & $\begin{array}{l}\mathbf{M} \\
\mathbf{F} \\
\mathbf{F} \\
\mathbf{F}\end{array}$ & $\begin{array}{l}\text { Alive and well } \\
\text { Alive and well } \\
\text { Alive and well } \\
\text { Sub-arachnoid haemorrhage } \\
\text { Alive and well }\end{array}$ & $\mathrm{DC}$ and $\mathrm{R}$ & $\begin{array}{l}d \\
d \\
d \\
c \\
d\end{array}$ \\
\hline $\begin{array}{l}\text { IV.61 } \\
\text { IV.62 } \\
\text { IV.63 } \\
\text { IV.64 }\end{array}$ & $\begin{array}{l}1935 \\
1938 \\
1935 \\
1930\end{array}$ & $\begin{array}{l}36 \\
33 \\
36 \\
41\end{array}$ & $\begin{array}{l}F \\
F \\
F\end{array}$ & $\begin{array}{l}\text { Alive and well } \\
\text { Alive and well } \\
\text { Alive and well } \\
\text { Alive and well }\end{array}$ & & $\begin{array}{l}d \\
d \\
d \\
d\end{array}$ \\
\hline
\end{tabular}

* Age at death is given in parentheses.

$+\mathrm{DC}=$ death certificate; $\mathrm{HR}=$ hospital records; $\mathbf{R}=$ other records; $\mathrm{GP}=$ family doctor.

$\ddagger$ For code a, b, c, d, see Fig. 1 . 